\title{
THE EFFECT OF LOCAL GOVERNMENT POLICIES AND SERVICES ON THE EMPOWERMENT OF CATTLE FARMERS IN SRAGEN
}

\author{
Tri Agus Bayuseno \\ Universitas Satyagama, Indonesia \\ Email :tri.agus.b@gmail.com
}

\begin{abstract}
Good service from the government to the community must be realized with the existence of policies that are impartial and beneficial for all members of the community (in this case cattle farmers). Therefore, the policies issued and the services provided by the government especially the local government are expected to have a significant influence on community empowerment in the region. With this, the author tries to examine the effect of the policies and / or services of the Local government on the empowerment of cattle farmers in Sragen Regency, Central Java. It is expected that the policies and / or services of the local government have a good influence on the empowerment of cattle farmers in this area and can be applied in other areas. The methodology used in this study combines several data collection and analysis techniques. In general, this study uses explanatory methods that describe and explain the relationship that occurs for each problem, until reaching a conclusion to answer the problems studied. The results of this study are expected to be the first step of further studies to jointly make the relationship between government and society increasingly and better.
\end{abstract}

Keywords: Policy, Services, Local Government, Empowerment, Cattle Farmers

\section{INTRODUCTION}

The development of beef cattle farms in Indonesia is basically aimed at increasing domestic meat production, in addition to other goals and enthusiasm to accelerate the cattle self-sufficiency program in Indonesia. This provides opportunities for farmers, especially small-scale beef cattle farms, to increase production so that the dependence on imported meat can be reduced. In this context, profits will occur if the farmer's income is higher and the production costs are low, so that the farmer will get greater profits. Indonesian cattle ranchers lack knowledge of good and correct ways to raise cattle, so meat productivity (Average Daily Gain (ADG)) or daily weight gain produced by cattle is low. On average, beef cattle farmers in Indonesia learn more downward, no new knowledge they receive from the knowledge of their ancestral heritage. Meanwhile, according to Dawud low quality beef is influenced by two factors, namely:

First, low cage sanitation and farmer behavior that has not led to good farming practice. Many farmers who build their cow sheds are integrated into the house for safety reasons. Livestock waste, both solid waste and liquid waste, has not been managed properly, causing pollution to the environment. Even though if the waste management is done properly it can provide added value to the business. The results of economic analysis show that the farming business system that implements clean production can provide significant benefits.

Second, the quality and quantity of feed is low. Most cattle farmers still provide low-quality feed to their livestock. Only consists of green food and natural grass, plus 
food crop waste. The cause of meat production in Sragen Regency is low because there are few people who want to become cattle ranchers, they assume if they become beef cattle ranchers will get a small profit and must be extra in the care and maintenance of their cattle.

In fact, there are many farmers who also become beef cattle farmers in Sragen Regency, where this is indeed very reasonable, considering that in Sragen Regency there are many green grasses available as fodder. The village government has a very important role in the empowerment of beef cattle farms, considering that the village is a system of government which is at the lowest level so that it is in direct contact with the lower levels of society, for example cattle ranchers. In its activities, the village head directly provides public services in the form of counseling to the community of cattle farmers.

Therefore, in many activities directly related to the community at the lower level, it is necessary to prepare careful planning and the need for forms of service that are able to provide maximum service so that people get satisfaction. Because one of the functions of the village head is about what kind of policy should be taken so that the village community gets what is needed to provide smoothness. In line with the above understanding the role of the Village Government is needed in the livestock world, this is marked by the emergence of various empowerments that are encouraged by the government, both by the Village Government, Regency Government and the Central Government. All this is done in order to advance cattle farmers.

The government is essentially a servant to the community, the government is realized to provide services to noncommunity people who serve the government, professional public services can be surprised by the government if there is accountability and responsibility of service providers in this case the government apparatus themselves. One of the most important tasks of government is to provide public services to the public as good as possible. but not infrequently also especially in Indonesia in reality, not all government officials realize the importance of service. The service is provided by the government through its apparatuses (employees / officers) to fulfill the public or individual interests, which are based on basic rights as citizens. the form can be in verbal services, written services and services in the form of acts.

Beef cattle farmers are one part of farmers to improve the quality of life in harmony with national development as a strategic tool to improve the welfare of the community, directed to form a whole human being, namely to develop the welfare of the Indonesian people as a whole. This foundation causes the scope of national development to be very broad, so the implementation must be planned, comprehensive, gradual and continued. At each stage it is expected that harmony in outward and inner progress will be achieved evenly covering all people, with increasing levels of social justice.

Protection of the rights owned by beef cattle farmers should not be ignored, if improving the quality of life is the goal. This protection can be done by promoting the law as a rule or norm in determining policies related to beef cattle farmers. Association or association that houses beef cattle farmers is a logical way to be able to carry out policies related to the obligations and rights possessed by beef cattle farmers. Association is important to talk about because this association is a forum that can logically influence the policy itself. Beef cattle farming individually when faced with policies that are unprofitable, has a lack of ability to conduct rejection of it.

To be more focused and focused in conducting research, the authors only limit the problem of this research by efforts to 
disclose information about the Policies and Services of Local Governments towards the Empowerment of Cattle Farmers in Sragen Regency.

Previous research similar to that of Faizatul Karimah, (2013), which examined the Management of Village Fund Allocation in Community Empowerment (Study in the Deket Kulon Village, Deket Sub-regency, Lamongan Regency). Normative and administrative management of village fund allocation in community empowerment in Deket Kulon Sub-regency, Dekongan Regency. However, in substance there are a number of things that need to be improved, namely community participation at the planning, supervision, accountability, and transparency stages which is not optimal because the community does not know much about these activities.
The main problem that will be examined in this study is the Empowerment of Cattle Farmers in Sragen Regency is not optimal or optimal. This is thought to be influenced by, among others, the low background of Local Government Policies and Services. Based on the statement of the problem, the problem needs to be limited to the extent of the influence of local government policies and services on the empowerment of cattle farmers in Sragen regency.

In this study the author will explain the framework used to determine the effect of each independent variable (variable $\mathrm{X}$ ) on the dependent variable (variable Y). The framework for research can be described as follows:

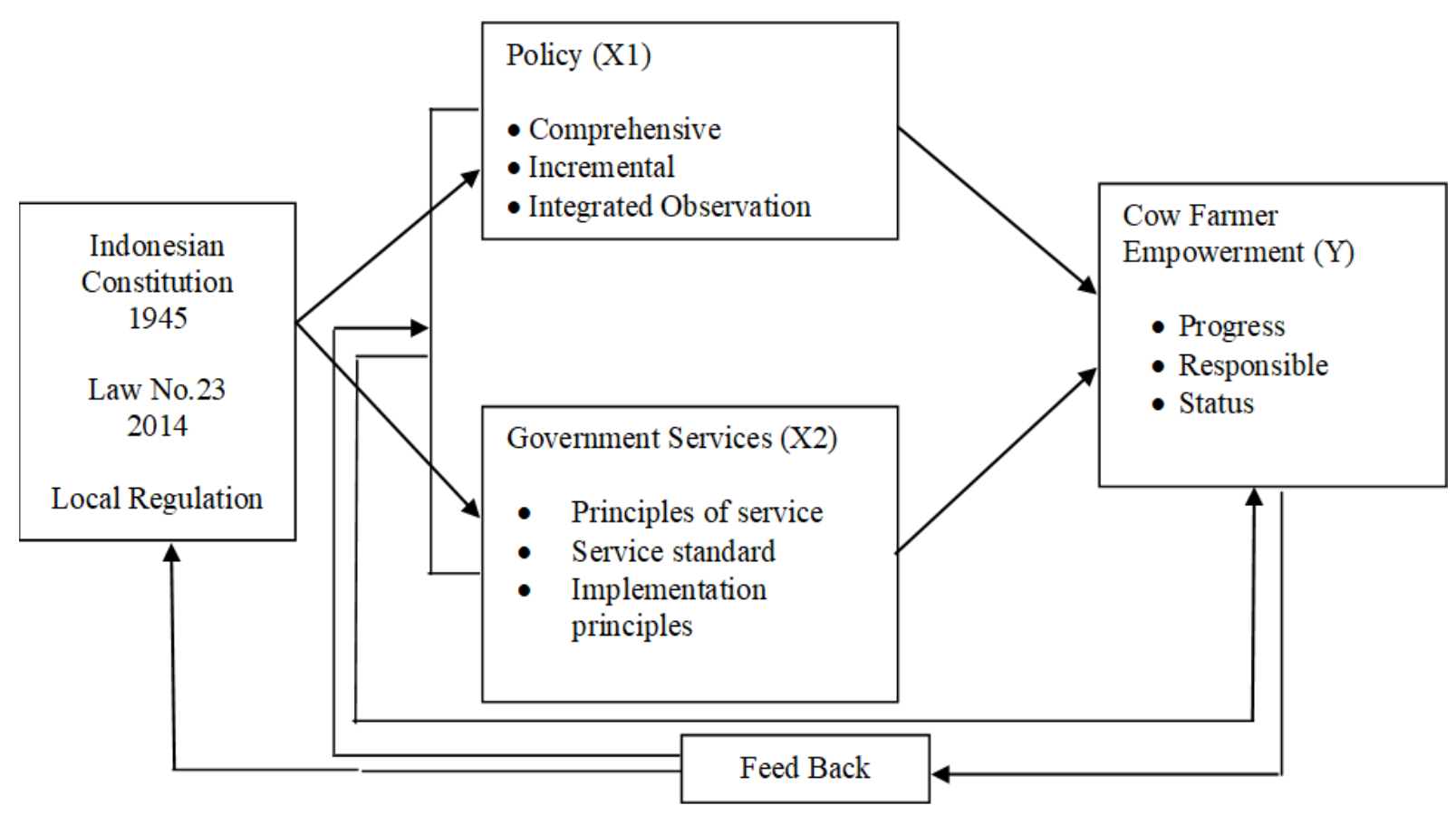

Figure 1. Research Framework

\section{RESEARCH METHODS}

In this study the authors used an explanatory method that describes, illustrates and explains and achieves answers about the influence of Government
Policies and Services on Empowering cattle farmers in Sragen Regency. The research was carried out according to the level of explanation that revealed the variables studied and explained the objects through 
the collected data. In this study, researchers used quantitative data in the form of numbers or qualitative data that was framed. Thus, the data obtained are complementary and integrated with each other, so that they can be accounted for and can solve problems.

Accordingly, the authors examine the interaction relationship between three independent variables (independent variables) consisting of Policy as factor X1 and Government Services as X2 while the dependent variable (dependent variable) is Empowerment of cattle farmers as $\mathrm{Y}$ factor, besides which there are other factors influential called Epsilon.

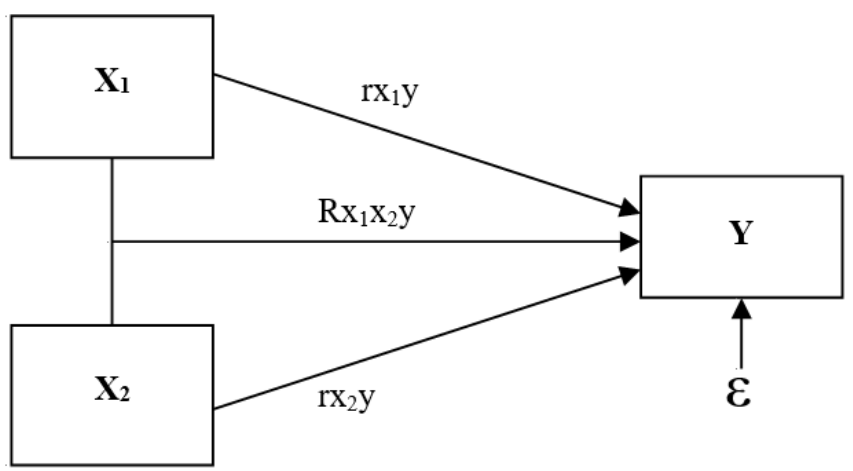

Figure 2. Research Methods

Source: Sugiyono, Business Research Methods (2004: 153)

Information:

$\mathrm{X}_{1} \quad=$ Policy

$\mathrm{X}_{2} \quad=\quad$ Government

services

$\mathrm{Y}=$ Empowerment of

cattle ranchers

$\varepsilon$ (Epsilon) $=$ Other factors that influence but not examined.

$\operatorname{rx}_{1} \mathrm{y}=$ The structural

parameters of the effect of $\mathrm{X}_{1}$ on $\mathrm{Y}$

$\mathrm{rx}_{2} \mathrm{y}=$ The structural

parameters of the effect of $\mathrm{X}_{2}$ on $\mathrm{Y}$

$\mathrm{Rx}_{1} \mathrm{x}_{2} \mathrm{y}=$ The structural

parameters influence

$\mathrm{X}_{1}$ and $\mathrm{X}_{2}$ together on

$\mathrm{Y}$

The data processed is the score obtained by the respondent in answering the questionnaire. There are 3 types of questionnaires that represent each variable. There are 15 items in each questionnaire that structured and measured parameters using a
Likert scale with a score of 1 to 5 (positive statements) and 5 to 1 negative statements.

In this study the authors determined the study population of 114 cattle ranchers. The sample in this study is that there are 35 cattle ranchers in the regency of Sragen. To determine the sample size, the authors use the formula model from Slovin (Azhari, 2002: 53), where:

$$
\begin{array}{rl}
\mathrm{n}= & \mathrm{N} \\
\mathrm{i} & \mathrm{N}(\mathrm{e})^{2} \\
= & -\mathrm{114} \\
& 1+114(0,1)^{2} \\
= & 35 \text { Samples }
\end{array}
$$

Dimana :

$$
\begin{array}{ll}
\mathrm{n} & =\text { number of samples } \\
\mathrm{N} & =\text { Total population }
\end{array}
$$


$\mathrm{e}=$ Error $(\%$ which can be tolerated against inaccurate use of samples instead of

$$
\text { population). }
$$

Supporting data used in this study can be in the form of theories put forward by experts as well as data obtained from organizations regarding the effect of Government Policies and Services on Empowering cattle farmers in Sragen Regency.

The author uses 2 types of data collection techniques, namely (1) field research techniques with questionnaires, interviews, and observations and (2) library research techniques to support the study of this research.

In order to measure the effect of Government Policies and Services on the Empowerment of cattle farmers in Sragen Regency, the author first conducts a validity and reliability test, a normality test, a correlation analysis of the questionnaire to be given to respondents. We use SPSS version 13.0.

The location of this research is slim in Sragen Regency, Central Java Province, Indonesia. The duration of the study is around 4 (four) months from the beginning of the activity in the form of preparation to the completion of the research report.

\section{RESULTS AND DISCUSSION A. Description of Research Data}

In this study, the variables used are two independent variables and one dependent variable. The two independent variables are Policy as the first independent variable (X1) and Government Services as the second independent variable (X2). While the dependent variable is Empowerment of cattle ranchers $(\mathrm{Y})$.

After calculating the answers given by 35 people who became the study sample, the summary of Policy variable data (X1) as one of the factors influencing the Empowerment of Cattle Farmers, can be seen in the table below:

Table 1. Statistical Data of Policy Variable (X1)

\begin{tabular}{|c|c|c|}
\hline & & $\mathrm{X}_{1}$ \\
\hline \multirow[t]{2}{*}{$\mathrm{N}$} & Valid & 35 \\
\hline & Missing & 0 \\
\hline \multicolumn{2}{|l|}{ Mean } & 59.4857 \\
\hline \multicolumn{2}{|c|}{ Std. Error of Mean } & 1.35868 \\
\hline \multicolumn{2}{|l|}{ Median } & $61.1667^{\mathrm{a}}$ \\
\hline \multicolumn{2}{|l|}{ Mode } & 59.00 \\
\hline \multicolumn{2}{|c|}{ Std. Deviation } & 8.03804 \\
\hline \multicolumn{2}{|c|}{ Variance } & 64.610 \\
\hline \multicolumn{2}{|l|}{ Skewness } & -.659 \\
\hline \multicolumn{2}{|c|}{ Std. Error of Skewness } & .398 \\
\hline \multicolumn{2}{|l|}{ Kurtosis } & 3.537 \\
\hline \multicolumn{2}{|c|}{ Std. Error of Kurtosis } & .778 \\
\hline \multicolumn{2}{|c|}{ Range } & 39.00 \\
\hline \multicolumn{2}{|l|}{ Minimum } & 32.00 \\
\hline \multicolumn{2}{|l|}{ Maximum } & 71.00 \\
\hline \multicolumn{2}{|l|}{ Sum } & 2082.00 \\
\hline \multirow[t]{2}{*}{ Percentiles } & 25 & $56.5625^{\mathrm{b}}$ \\
\hline & 50 & 61.1667 \\
\hline
\end{tabular}


a. Calculated from grouped data.

\begin{tabular}{l|l}
75 & 64.5000
\end{tabular}

b. Multiple modes exist. The smallest value is shown

c. Percentiles are calculated from grouped data.

Source: data processing by the researcher (2018)

From the statements made by the respondents on the questionnaire given to them to the Policy the percentage of questions is as follows:

a. $(32.6 \%)$ of respondents stated strongly agree with 171

b. $(42.7 \%)$ of respondents stated that they agree with 224

c. $(14.4 \%)$ of respondents stated that they disagreed amounted to 76

d. $(9.3 \%)$ of respondents said that they did not agree with 49 e. (1\%) of respondents stated strongly disagreed amounting to 5

Based on the figures above it can be concluded that the majority of respondents agreed with the Policy in increasing the Empowerment of Cattle Farmers.

For a summary of the variable data Local Government Services (X2) as one of the factors that affect the Empowerment of Cattle Farmers, can be seen in the table below:

Table 2. Statistical Data of Local Government Service Variable (X2)

\begin{tabular}{|c|c|c|}
\hline & & $\mathrm{X}_{2}$ \\
\hline \multirow[t]{2}{*}{$\mathrm{N}$} & Valid & 35 \\
\hline & Missing & 0 \\
\hline \multicolumn{2}{|l|}{ Mean } & 57.9143 \\
\hline \multicolumn{2}{|c|}{ Std. Error of Mean } & 1.58320 \\
\hline \multicolumn{2}{|c|}{ Median } & $59.0000^{\mathrm{a}}$ \\
\hline \multicolumn{2}{|l|}{ Mode } & 58.00 \\
\hline \multicolumn{2}{|c|}{ Std. Deviation } & 9.36631 \\
\hline \multicolumn{2}{|l|}{ Variance } & 87.728 \\
\hline \multicolumn{2}{|l|}{ Skewness } & -.1599 \\
\hline \multicolumn{2}{|c|}{ Std. Error of Skewness } & .398 \\
\hline \multicolumn{2}{|l|}{ Kurtosis } & 2.845 \\
\hline \multicolumn{2}{|c|}{ Std. Error of Kurtosis } & .778 \\
\hline \multicolumn{2}{|l|}{ Range } & 43.00 \\
\hline \multicolumn{2}{|l|}{ Minimum } & 30.00 \\
\hline \multicolumn{2}{|l|}{ Maximum } & 73.00 \\
\hline \multicolumn{2}{|l|}{ Sum } & 2027.00 \\
\hline \multirow[t]{3}{*}{ Percentiles } & 25 & $56.4167^{\mathrm{b}}$ \\
\hline & 50 & 59.0000 \\
\hline & 75 & 63.1250 \\
\hline
\end{tabular}

a. Calculated from grouped data.

b. Multiple modes exist. The smallest value is shown

c. Percentiles are calculated from grouped data.

Source: data processing by the researcher (2018)

From the statements made by the respondents on the questionnaire given to 
them, towards the Local Government Service, the percentage of questions is as follows:

a. $(25.1 \%)$ of respondents stated strongly agree totaling 132

b. $(48.3 \%)$ of respondents stated that they agreed to be 254

c. $(15.7 \%)$ of respondents stated that they disagreed amounted to 82

d. $(9.1 \%)$ of respondents said that they did not agree amounted to 48 e. $(1.8 \%)$ of respondents stated strongly disagreed amounted to 9

Based on the figures above it can be concluded that the majority of respondents agreed with the Local government Services in increasing the Empowerment of Cattle Farmers.

While the summary data of the Cattle Farmer Empowerment (Y) variable as one of the factors affected can be seen in the table below:

Table 3. Statistical Data of Cattle Farmers Empowerment Variables (Y)

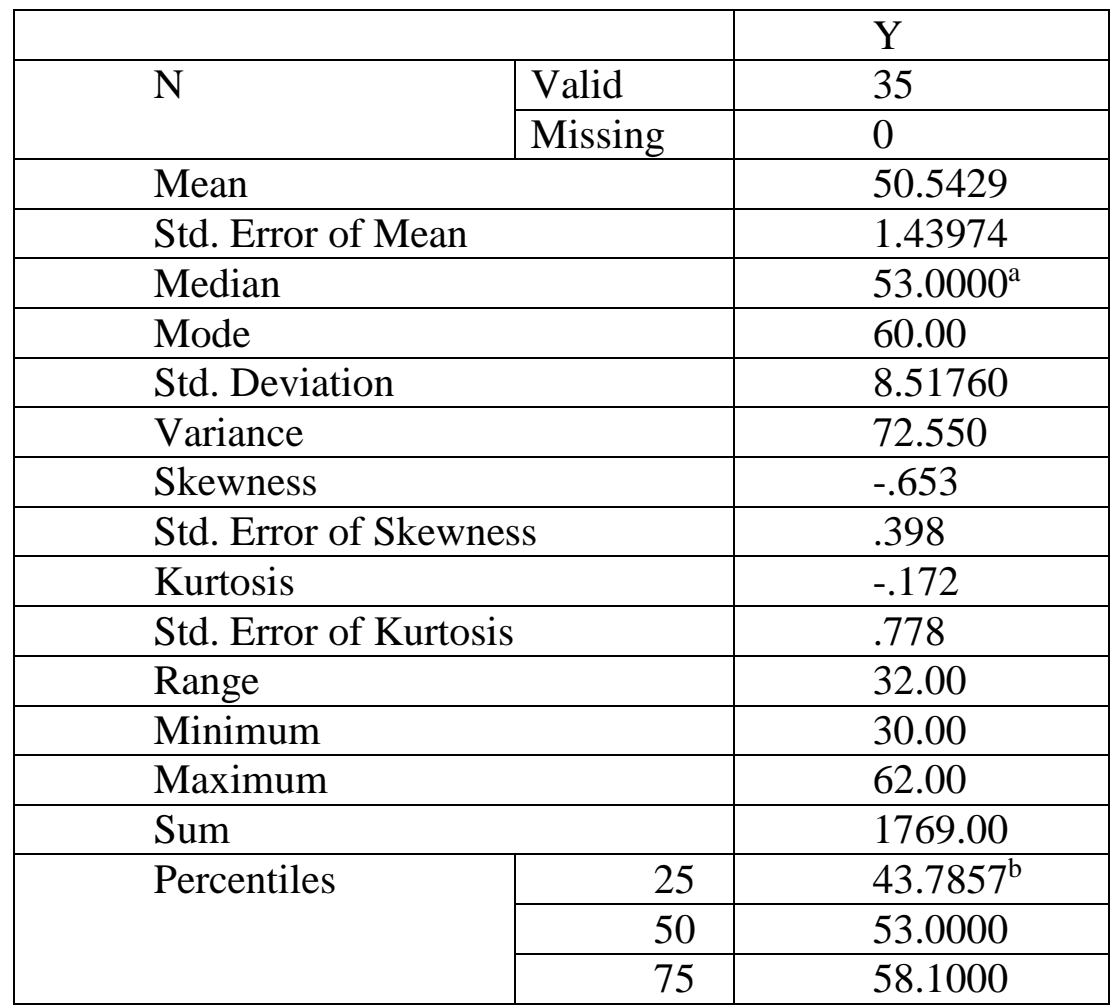

a. Calculated from grouped data.

b. Multiple modes exist. The smallest value is shown

c. Percentiles are calculated from grouped data.

Source: data processing by the researcher (2018)

From the statements made by the respondents in the questionnaire given to them, against the Empowerment of Cattle Farmers, the percentage of questions is as follows:

a. $(42.7 \%)$ of respondents stated strongly agree with 224 b. $(50.7 \%)$ of respondents stated agree totaling 266

c. $(5.9 \%)$ of respondents stated that they disagreed amounted to 31

d. $(0.7 \%)$ of respondents stated disagreed amounted to 4

e. $(0 \%)$ of respondents stated strongly disagree with 0 
Based on the figures above it can be concluded that the majority of respondents agree with the Empowerment of Cattle Farmers.

\section{B. Testing of Data Analysis and Hypotheses}

From testing of data analysis with SPSS 13, it was found that all data is valid and worthy of being the result of research.

To test the hypothesis the author uses two kinds of tests, namely the $t$ test and the $\mathrm{F}$ test. The formulation of the hypothesis to be tested is given the symbol $\mathrm{H} 0$, while for the alternative hypothesis is given the symbol H1. Statistical hypothesis testing for the first and second hypotheses is done by $\mathrm{t}$ test, while the third hypothesis is done by $\mathrm{F}$ test.

1. T-test for $b_{1}$

T-test for $b_{1}$ conducted to test the first hypothesis, namely:

Ho : $b_{1}=0$; there is no influence of the

Policy on the Empowerment of Cattle Farmers.

$\mathrm{H}_{\mathrm{a}}: \mathrm{b}_{1} \neq 0$; there is an influence of the

Policy on Empowerment of Cattle Farmers.

If $\mathrm{t}$-count $>\mathrm{t}$-table, then $\mathrm{Ho}$ is rejected and Ha is accepted.

$\mathrm{T}$ test results with the help of computer processing, the coefficient of $\mathrm{t}$ count for $b_{1}$ is obtained as follows:

Table 4

$\mathrm{T}$ Test of Policy Variable (X1)

\begin{tabular}{|r|r|r|r|r|r|}
\hline \multirow{2}{*}{ Model } & \multicolumn{2}{|c|}{ Unstandardized Coefficient } & \multicolumn{1}{c|}{$\begin{array}{c}\text { Standardized } \\
\text { Coefficient }\end{array}$} & \multirow{2}{*}{$\mathrm{t}$} & \multirow{2}{*}{ ig } \\
\cline { 2 - 4 } & \multicolumn{1}{|c|}{$\mathrm{B}$} & Std. Error & Beta & & \\
\hline 1 (constant) & 26.957 & 2.134 & & 12.632 & .000 \\
$\mathrm{X} 1$ & .345 & .039 & -.038 & 8.846 & .000 \\
\hline
\end{tabular}

a. Dependent Variable: Y

From the calculations, the $t$-count obtained was 8.846 , while the t-table with 32 degrees of freedom at $\alpha(0.05)$ was 2.021. Thus t-count $>\mathrm{t}$-table, so clearly Ho is rejected and $\mathrm{Ha}$ is accepted. This shows that the policy has a positive and significant effect on the Empowerment of Cattle Farmers.

\section{T-test for $b_{2}$}

T-test for $b_{2}$ conducted to test the second hypothesis, namely:

Ho : $b_{2}=0$; there is no influence of Local Government
Services on Empowerment of Cattle Farmers.

$\mathrm{Ha}: \mathrm{b} 2 \neq 0$; there is an influence of Local Government Services on Empowerment of Cattle Farmers.

If $\mathrm{t}$-count $>\mathrm{t}$-table, then $\mathrm{Ho}$ is rejected and $\mathrm{Ha}$ is accepted.

$\mathrm{T}$ test results with the help of computer processing, the coefficient of $\mathrm{t}$ count for b2 is obtained as follows:

Table 5. T test of Local Government Services Variable (X2)

\begin{tabular}{|r|r|r|r|r|r|}
\hline \multirow{2}{*}{ Model } & \multicolumn{2}{|c|}{ Unstandardized Coefficient } & $\begin{array}{c}\text { Standardized } \\
\text { Coefficient }\end{array}$ & \multirow{2}{*}{$\mathrm{t}$} & \multirow{2}{*}{ Sig } \\
\cline { 2 - 4 } & \multicolumn{1}{|c|}{$\mathrm{B}$} & \multicolumn{1}{|c|}{ Std. Error } & \multicolumn{1}{|c|}{ Beta } & & \\
\hline 1 (constant) & 26.957 & 2.134 & & 12.632 & .000 \\
X2 & .360 & .161 & -.428 & 2.143 & .000 \\
\hline
\end{tabular}


From the calculations, the t-count obtained was 2,143 , while the $t$-table with 32 degrees of freedom at $\alpha(0.05)$ was 2,021 . Thus $t-$ count > t-table, so clearly Ho is rejected and $\mathrm{Ha}$ is accepted. This shows that Local Government Services have a positive and significant effect on the Empowerment of Cattle Farmers.

\section{F Test}

$F$ test is performed to test the third hypothesis, namely:

Ho : $b_{1}=b_{2}=0$; there is no influence of Local government Policies and
Services together on the Empowerment of Cattle Farmers.

$H_{a}: b_{1}: b_{2} \neq 0$; There is an influence of

Local Government Policies and

Services together on the

Empowerment of Cattle Farmers.

If $\mathrm{F}$ count $>\mathrm{F}$ table, then $\mathrm{Ho}$ is rejected and $\mathrm{Ha}$ is accepted.

The results of the $\mathrm{F}$ test with the help of computer processing show the coefficient $F$ value is obtained as follows:

Table 6. F-count of Policy Variable (X1) and Local Government Services variable (X2) together on the Empowerment of Cattle Farmers variable (Y)

ANOVA

\begin{tabular}{|ll|r|r|r|r|c|}
\hline Model & & \multicolumn{1}{c|}{$\begin{array}{c}\text { Sum of } \\
\text { Squares }\end{array}$} & df & Mean Square & F & Sig. \\
\hline 1 & Regression & 37.287 & 2 & 78.644 & 20.072 & $.001^{\mathrm{a}}$ \\
& Residual & 2429.398 & 32 & 3.919 & & \\
& Total & 2466.686 & 34 & & & \\
\hline
\end{tabular}

a. Predictors: (Constant), X2, X1

b. Dependent Variable: $Y$

Based on the calculation results, obtained Fcount20,072, while the critical value of the value of $\mathrm{F}$ table with a numerical degree of freedom 2 and the denominator 32 at $\alpha$ (0.05) is 3.30. Thus F-count > F-table, so clearly $\mathrm{Ho}$ is rejected and $\mathrm{Ha}$ is accepted. This shows that together Local Government Policies and Services have a positive and significant effect on the Empowerment of Cattle Farmers.

\section{Discussion of Research Results}

\section{Implementation of Policies on} Empowerment of Cattle Farmers.

The extent to which a policy is successful in society is largely determined by the formulation of that policy. many policies are generally seen by experts as quite good, but have not been implemented successfully in the community so that they have not succeeded in achieving the expected goals. Conversely there are policies that appear to be of poor quality in terms of substance, but are accepted by the community because they represent their aspirations, even though there are many shortcomings in achieving the goals.

Viewed from here there are two factors that determine the success of a policy. First, the quality of the policy is seen from the substance of the formulated policy. This can be seen in the truth of identifying 
the problem precisely. The truth of identifying problems correctly means that the problems identified are not only true in the sense of plausible or reasonable, but also can be handled (actionable) seen in various facilities and conditions that exist and may be attempted. The determination of the problem is always debatable, but what is meant here is that at least the procedures adopted can be scientifically justified. In addition, there is also a formulation of the right strategy. And second, there is support for the formulated policy strategy. Without sufficient support, policies cannot be realized.

From the results of the analysis, tcount was obtained at 8.846 while t-table with 32 degrees of freedom at $\alpha(0.05)$ was 2.021. Thus t-count $(8,846)>t$-table $(2,021)$, so clearly Ho was rejected and Ha was accepted. This shows that the policy has a positive and significant effect on the empowerment of cattle farmers. While the correlation coefficient value is $\mathrm{rx} 1 \mathrm{y}=0.759$ and the coefficient of determination is 0.576 (57.6\%). This means that this relationship shows strong because it is between 0.60 0.79 which means that if the policy is good, the empowerment of cattle farmers is also good.

\section{Effect of Local Government Services on Empowerment of Cattle Farmers.}

The application of services also does not mean only increasing the level of service, but it is a process of service renewal that must be continuously carried out, in order to meet the increasing demands of society. For this purpose, one can proceed by following the service development cycle as follows:

a. Design renewal: at this stage it is necessary to understand, map, review and update the added value that can actually be provided by the service process for the community. The assessment must be carried out in detail and thoroughly from the beginning to the end of the service process. This stage is very strategic, because it provides a great opportunity to create services that are able to reflect the principles of service, and that have the capacity for the latest concepts from various fields of study.

b. Socialization and coordination: after the value added map can be updated, then it needs to be socialized to the executive officers, and customers. In addition, this map also needs to be shared with suppliers so that they can fully support its implementation.

c. Preparation of service standards: based on a value added map that has been understood by both the implementing officer and the customer, and has also been agreed to be supported by the supplier, a standard service and quality assurance procedure can be written.

Improved service is essentially an effort to influence the strengths and weaknesses inherent in every human being as well as factors that can help or hinder quality improvement. Maintaining or increasing strength with proper utilization will improve the quality of human beings, as well as efforts to eliminate or at least reduce weaknesses in humans can also increase their productivity and also know the conditions of assistance and obstacles outside the employee concerned.

From the results of the analysis, the value of t-count was 2.143 while the t-table with 32 degrees of freedom at $0,0(0.05)$ was 2.021. So t-count $(2.143)>\mathrm{t}$-table $(2.021)$, so that Ho was clearly rejected and $\mathrm{Ha}$ was accepted. This shows that Local Government Services have a positive and significant influence on the Empowerment of cattle ranchers. While the coefficient value is $\mathrm{rx} 2 \mathrm{y}=0.870$ and the coefficient of determination is $0.756(75.6 \%)$. This means that this relationship shows strong because it is between $0.60-0.79$ which means that if the Local government Services are good, the 
Empowerment of Cattle Farmers is also good.

\section{Effect of Local Government Policies and Services Together on the Empowerment of Cattle Farmers.}

The empowerment of cattle farmers actually has value for cattle farmers, because it is evidence of reference, among others, to the achievements they have achieved while working in an organization. A promoted cattle rancher is considered to have a satisfying existing achievement. Empowerment has an important meaning for an organization, because with the development of cattle farmers, it means that organizational stability and employee morale will be guaranteed. Both of the above must be minimally caused if an organization develops a cattle farmer.

In choosing instructors, it is necessary to meet the requirements that must be met by each instructor in the implementation of the development of cattle ranchers in order to be carried out effectively and efficiently. With the existence of farmer development programs is a basic requirement, both in terms of the organization and its employees concerned. For dynamic cattle ranchers, the need for self-development is an encouragement to work more actively and more productively, so that it has an effect on work performance henceforth for employees who expect a career to be better than cattle ranchers who do not expect a career, so instead selfdevelopment is a way to achieve the ideals desired from himself and for his organization.

From the analysis results obtained Fcount of 20.072, while the critical value of the value of F-table with a degree of numerator 2 free and the denominator 32 at $\alpha(0.05)$ of 3.30. Thus F-count $>$ F-table, so clearly $\mathrm{Ho}$ is rejected and $\mathrm{Ha}$ is accepted. This shows that together with the policies and services of the local government significantly influence the Empowerment of
Cattle Farmers. the value of the correlation coefficient $(\mathrm{Rx} 1, \mathrm{x} 2 \mathrm{y})=0.865$ and the coefficient of determination of 0.748 $(74.8 \%)$. This means that this relationship shows strong because it is between 0.60 0.79 which means that if the Local Government Policy and Services are good, the Empowerment of Cattle Farmers is also good or vice versa.

\section{CONCLUSION AND RECOMMENDATION}

Based on the results of research and discussion, it can be concluded that the policies and / or services of the Sragen Regency Government have a positive and significant effect on the Empowerment of Cattle Farmers in Sragen Regency. With good policies and good services, the Empowerment of Cattle Farmers in Sragen Regency will also develop into good.

With this the author suggests that in the future can make the policy as guidelines for implementation, both positive and negative. The policy should be made to have enough information about various alternatives related to cattle breeding issues such as how to maintain and increase the daily weight gain (ADG) of cattle properly. Then, for all employees it is necessary to provide good and transparent service, so that it is easy and accessible to all parties who need it and is provided sufficiently and easily understood.

In the future, there must be mentoring and regeneration of employees, so that there is an even distribution of skills between employees which is expected to be able to encourage other employees to work better. Especially for employees who have good work experience in solving problems related to the scope of the cattle. 


\section{REFERENCES}

\section{Books:}

Sunyoto, A. 2000. Pengembangan Sumber Daya Manusia. Erlangga. Jakarta.

Kusriyanto, B. 2002. Meningkatkan Produktivitas Pegawai. Titian Ilmu. Yogyakarta.

Winarno, B. 2007. Kebijakan Publik: Teori dan Proses. Media Presindo. Yogyakarta.

Juliantara, D. 2005. Peningkatan Kapasitas Pemerintah Dalam Pelayanan Publik. Pembaruan. Yogyakarta.

Catherine, D. 2001. Good Service is Good Business. Gramedia Pustaka Utama. Jakarta.

Gaspersz, V. 2001. Manajamen Kualitas Dalam Industri Jasa. Gramedia Pustaka Utama. Jakarta.

Malayu, H. 2006. Organisasi dan Motivasi. Haji Masagung. Jakarta.

Irfan, I. 1997. Prinsip-prinsip Perumusan Kebijakan Negara. Bumi Aksara. Jakarta.

Kast, F.E. and Rosenzweig, J.E. 2003. Organization and Management: $A$ System Approach. Mc Graw Hill Book Company. New York.

Widodo, J. 2008. Analisis Kebijakan Publik: Konsep dan Aplikasi Analisis Proses Kebijakan Publik. Bayumedia Publishing. Malang.

Jones, Charles O. 2000. An Introduction to the Study of Public Policy, $2^{\text {nd }}$ Ed. Duxbury Press. North Scituate, MA.

Kansil. 2005. Hukum Tata Pemerintahan Indonesia. Bina Aksara. Jakarta.

Koswara, Kertapradja. 2009. Otonomi Daerah. Yayasan Pariba, Universitas Satyagama. Jakarta.

Kotter, J.P. and Heskett, J.L. 1992. Corporate Culture and Performance, The Free Press. New York.
Parasuraman. A., Valarie A. Zeithaml, and Leonard L. Berry. 2000. A Conseptual Model of Service Quality and Its Implications for Future Research. Journal of Marketing, vol. 49 (Fall).

Rasyid, M.R. 2000. Makna Pemerintahan Tinjauan Dari Segi Etika dan Kepemimpinan Era Globalisasi. Ramadhan. Bandung.

Heidjrachman, R. and Husnan, Suad. 2002. Manajemen Personalia. Arwido Jaya. Semarang.

Moekijat. 2002. Dasar-dasar Administrasi dan Manajemen Perusahaan. CV. Mandar Maju. Bandung.

As'ad, M. 2005. Psikologi Industri, Seri Ilmu Sumber Daya Manusia. Liberty. Yogyakarta.

Nisjar, Karhi. 2009. Teori Sistem dan Pendekatan Sistem Dalam Bidang Manajemen. Mandar Maju, Bandung.

Nurmandi, A. 2000. Manajemen Perkotaan, Aktor, Organisasi dan Pengelolaan Daerah Perkotaan Di Indonesia. Lingkungan Bangsa. Yogyakarta.

Sianipar. 2000. Manajemen Pelayanan Masyarakat. LAN-RI, Jakarta.

Sinambela, P. 2006. Reformasi Pelayanan Publik. Bumi Aksara, Jakarta.

Suhardy. 2000. Pelayanan Publik di Era Reformasi. Ghalia Indonesia, Jakarta.

Suradinata, E. 2008. Manajemen Pemerintahan dan Otonomi Daerah. CV. Ramadhan, Bandung.

Ndraha, T. 2000. Pembangunan Mempersiapkan Masyarakat Tinggal Landas. Rineka Cipta, Jakarta. 2001. Teori Administrasi dan Pelayanan. BKU IP IIP, Jakarta.

Supriatna, T. 2016. Paradigma Manajemen Birokrasi dan Kebijakan Publik.

Tjiptono, F. 2001. Kualitas Jasa: Pengukuran, Keterbatasan dan Implikasi. Penerbit Andi Offset, Yogyakarta.

Tjosvold. 2003. Manajemen Pelayanan. Erlangga, Jakarta. 
Wahab, Solichin Abdul. 2002. Pengantar Analisis Kebijaksanaan Negara. Rineka Cipta, Jakarta.

Rokhman, W. 2003. Pemberdayaan Dan Komitmen: Upaya Mencapai Kesuksesan Organisasi Dalam Menghadapi Persaingan Global. Amara Books, Yogyakarta.

\section{Legislation:}

Law Number 25 Year 2009 Article 4, regarding the Implementation of Public Services.

Law No. 32 of 2004 concerning the notion of "Government".

Law No. 22 of 1999 concerning Local government

Law No. 23 of 2014 concerning Local government 